\title{
Chromosome number of two Chilean species of Nothofagus (Nothofagaceae)
}

\section{Número cromosómico de dos especies chilenas de Nothofagus (Nothofagaceae)}

\author{
Pedro Jara-Seguel ${ }^{1,2}$, Paz Cárcamo-Fincheira ${ }^{1}$, Claudio Palma-Rojas ${ }^{3} \&$ Elisabeth von Brand ${ }^{4}$ \\ ${ }^{1}$ Escuela de Ciencias Ambientales, Facultad de Recursos Naturales, Universidad Católica de Temuco, Casilla 15-D, Temuco- \\ Chile. \\ ${ }^{2}$ Núcleo de Estudios Ambientales (NEA), Universidad Católica de Temuco, Chile. \\ ${ }^{3}$ Departamento de Biología, Facultad de Ciencias, Universidad de La Serena, Casilla 599, La Serena-Chile. \\ ${ }^{4}$ Departamento de Biología Marina, Facultad de Ciencias del Mar, Universidad Católica del Norte, Casilla 117, Coquimbo, \\ Chile. \\ pjara@uct.cl
}

\section{RESUMEN}

Se documenta un número cromosómico $2 \mathrm{n}=26(\mathrm{x}=13)$ para Nothofagus dombeyi (Mirb.) Oerst. y N. glauca (Phil.) Krasser, el cual es similar al descrito previamente para otras especies del género. Se incrementan a 13 las especies de Nothofagus con número cromosómico conocido, existiendo dos números básicos $(\mathrm{x}=13,14)$.

Nothofagus Blume (Nothofagaceae) is a representative genus of the Gondwanean flora that includes 35 species of trans-antarctic and disjunct distribution, which is subdivided into four subgenera (Hill \& Read 1991, Hill \& Jordan 1993, Manos 1997). In South America the species of Nothofagus occur in Southern Chile and Argentina, whereas in Oceania, they occur in New Zealand, Tasmania, East Australia, New Caledonia and New Guinea. In Chile, nine species and one hybrid have been taxonomically recognized inhabiting from $33^{\circ} \mathrm{S}$ to $56^{\circ} \mathrm{S}$, covering the Central Valley, and Andean and Nahuelbutan slopes (Manos 1997, Donoso et al. 2004). Systematic studies carried out in Nothofagus have analyzed various characters of extinct species and fossils (Jordan \& Hill 1999). In this way, the phylogenetic framework of Nothofagus is abundant, including morphological and/or molecular analysis (Hill \& Jordan 1993, Martin \& Dowd 1993, Manos 1997, Setogushi et al. 1997, Jordan \& Hill 1999, Premoli et al. 2012). However, despite these advances, some aspects on the evolution of Nothofagus remain obscure, for example, the mechanism on chromosome evolution related with the origin of the genus and species differentiation. On this respect, chromosome numbers and/or qualitative karyotype studies have been previously reported for 11 species of Nothofagus (30.5\% of the species of the genus), seven of them inhabit various countries from Oceania (Armstrong \& Wylie 1965, Wardle 1967, Ono 1977, Carr \& McPherson 1986, Oginuma et al. 1998, Wiltshire \& Jackson 2003), and four occurring in Chile (Ono 1977) (Table I). The most frequent chromosome number described within the genus is $2 \mathrm{n}=26$ (Ono 1977, Dawson 2000), although one species from Oceania has been reported having a diploid number of $2 \mathrm{n}=28$ ( N. cunninghamii (Hook.) Oerst.; Wiltshire \& Jackson 2003). Interestingly, all four Chilean species studied so far show a diploid chromosome number $2 \mathrm{n}=26$. However, it is possible that both $2 \mathrm{n}$ numbers $(26$ or 28) can be present in other species distributed along Chile. To increase the cytogenetic data of Nothofagus, in this study the chromosome number of $N$. dombeyi (Mirb.) Oerst. and $N$. glauca (Phil.) Krasser are reported for the first time.

Young plants of $N$. dombeyi and $N$. glauca were obtained from CONAF Nursery, Chile, Región de La Araucanía, Provincia de Cautín, km 28 Temuco-Nueva Imperial road. The voucher specimens were deposited in the Herbarium of the Universidad Católica de Temuco. To obtain mitotic metaphases, the protocol described by Ono (1977) was followed. Root tips were cut in the morning and pretreated with a $2 \mathrm{mM}$ solution of 8 -Hydroxiquinoline for $3 \mathrm{~h}$ at a temperature of $18^{\circ} \mathrm{C}$. After fixation with $45 \%$ acetic acid during $0.5-2 \mathrm{~h}$, the material was hydrolyzed with a mixed solution of $1 \mathrm{~N} \mathrm{HCl}$ and $45 \%$ acetic acid $(1: 1 \mathrm{v} / \mathrm{v})$ at $60{ }^{\circ} \mathrm{C}$ during $10 \mathrm{~min}$ and then stained with acetic orceine $2 \%$ by 24 h. The mitotic metaphases were obtained by squashing the root tips and photographed with a digital camera Olympus C-5050 connected to an Olympus microscope CX31. Three plants per each species were examined and the chromosome counts were made in ten metaphases of each of them.

The results of the chromosome count show for $N$. dombeyi and $N$. glauca a number $2 \mathrm{n}=26$ (Fig. 1a, 1b). The basic number, $\mathrm{x}=13$, is the most frequent within this genus, being present in 12 species, which is additional to 
number $\mathrm{x}=14$ present in $N$. cunninghamii (Hook.) Oerst. from Tasmania (Armstrong \& Wylie 1965, Wardle 1967, Ono 1977, Dawson 2000, Wiltshire \& Jackson 2003). These results increase to 13 the species of Nothofagus with available chromosome data (36\% of the genus), which represent all four subgenera proposed by Hill \& Read (1991) (e.g., Lophozonia, Fucospora, Nothofagus, and Brassospora).
In an evolutionary context, Ono (1977) compiled the chromosome data available until then for Nothofagus, and resumed some interpretations on possible ancestors. Thus, one hypothesis suggested Nothofagus as a specialized offshoot of Fagus (Fagaceae) whose basic number is $\mathrm{x}=12$ chromosomes (Harris 1956, Hair 1966). Other alternative hypothesis suggest Nothofagus as a reduced form of an ancestral type with $\mathrm{x}=14$ chromosomes (Armstrong \&
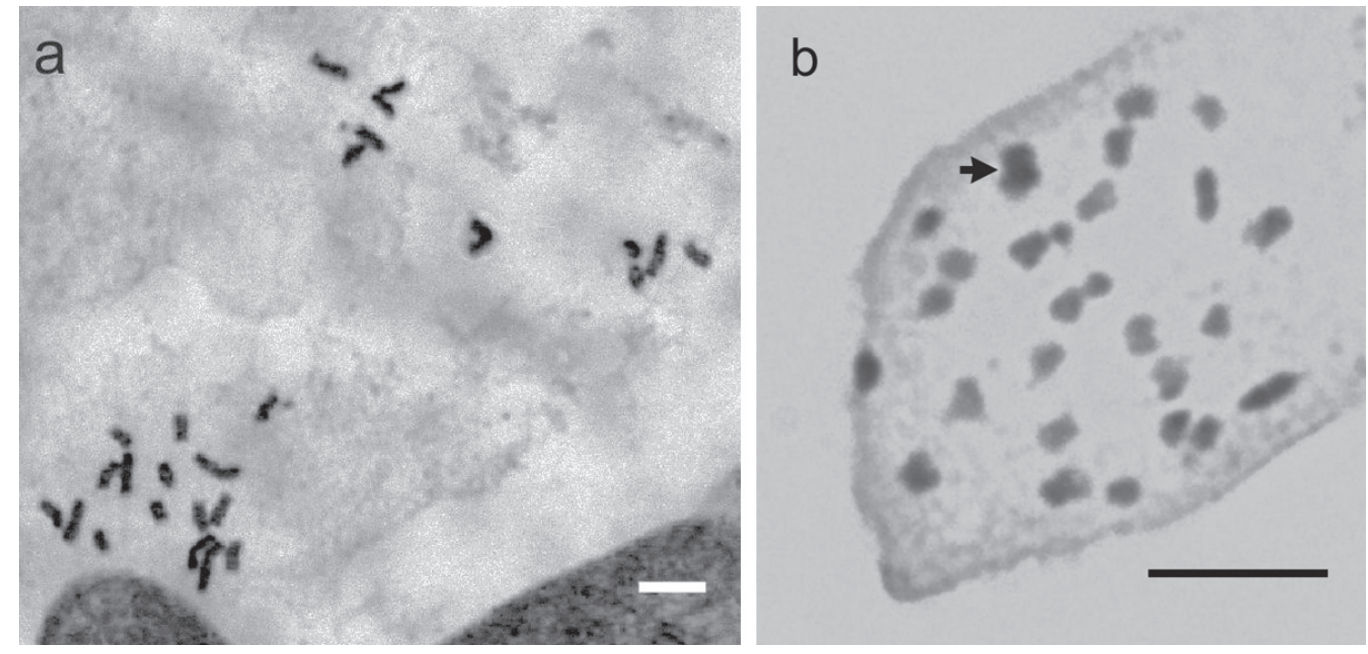

Figure 1. Mitotic metaphases of: a) N. dombeyi, and b) N. glauca. $2 \mathrm{n}=26$. Arrow shows two super-imposed chromosomes. Bar $=5 \mu$ m.

Figura 1. Metafases mitóticas de: a) $N$. dombeyi y b) $N$. glauca. $2 \mathrm{n}=26$. La flecha muestra dos cromosomas superpuestos. Barra $=5 \mu$ m.

TABLE I. Chromosome number and collection sites of Nothofagus species studied so far. The sub-generic classification was based on Hill \& Read (1991).

Tabla I. Número cromosómico y sitios de colecta de especies de Nothofagus estudiadas a la fecha. La clasificación subgenérica se basa en Hill \& Read (1991).

\begin{tabular}{|c|c|c|c|}
\hline SubGenus / SPecies & Collection SITES & $2 \mathrm{~N}$ & REFERENCE \\
\hline \multicolumn{4}{|l|}{ Lophozonia } \\
\hline Nothofagus alpina (Poepp. \&Endl.) Oerst. & Provincia de Nuble, Chile & 26 & Ono (1977) \\
\hline N. cunninghamii (Hook.) Oerst. & Tasmania & 28 & Wiltshire \& Jackson (2003) \\
\hline N. glauca (Phil.) Krasser & Temuco, Nursery specimens, Chile & 26 & Present study \\
\hline N. menziesii (Hook.) Oerst. & New Zealand & 26 & Armstrong \& Wylie (1965) \\
\hline N. obliqua (Mirb.) Oerst. & Temuco, Provincia de Cautín, Chile & 26 & Ono (1977) \\
\hline \multicolumn{4}{|l|}{ Fucospora } \\
\hline N. fusca (Hook.) Oerst. & New Zealand & 26 & Armstrong \& Wylie (1965) \\
\hline N. solandri (Hook.) Oerst. & New Zealand & 26 & Armstrong \& Wylie (1965) \\
\hline N. truncata (Col.) Ckn. & New Zealand & 26 & NZPCN (2013) \\
\hline \multicolumn{4}{|l|}{ Nothofagus } \\
\hline N. antarctica (Forst) Oerst. & Antillanca, Provincia de Llanquihue, Chile & 26 & Ono (1977) \\
\hline N. dombeyi (Mirb.) Oerst. & Temuco, Nursery specimens, Chile & 26 & Present study \\
\hline N. pumilio (Poepp. \& Endl.) Krasser. & Antillanca, Provincia de Llanquihue, Chile & 26 & Ono (1977) \\
\hline \multicolumn{4}{|l|}{ Brassospora } \\
\hline N. discoidea (Baum.-Bod.) Steenis & New Caledonia & 26 & Carr \& McPherson (1986) \\
\hline N. grandis Steenis & New Guinea & 26 & Oginuma et al. (1998) \\
\hline
\end{tabular}


Wylie 1965). On the basis of multiple lines of evidence compiled in later decades the first hypothesis was discard (Hill \& Jordan 1993, Manos \& Stanford 2001). Regarding the second hypothesis, it may be supported by the current cytogenetic evidence available for Nothofagus which shows that one species has 28 chromosomes ( $N$. cunninghamii with $\mathrm{x}=14$ ), being included within the subgenus Lophozonia together with other species having 26 chromosomes (Dawson 2000, Wiltshire \& Jackson 2003). Thus, the existence of an ancestor with $\mathrm{x}=14$ chromosomes is possible, which may be closest to $N$. cunninghamii. Interestingly, this observation is consistent with the topologies described by Setogushi et al . (1997) as revealed by molecular phylogenies, hypothesizing that during the evolution of Nothofagus the subgenus Lophozonia derived first, followed later by Fucospora, Nothofagus and Brassospora, respectively. Then, based on these arguments, it is possible that the subgenus Lophozonia retain most ancestral characters, as was described in the male inflorescence (Hill \& Jordan 1993), and in the basic number $\mathrm{x}=14$ present in $N$. cunninghami. Nevertheless, this partial cytogenetic evidence available for Nothofagus based upon the chromosome number should be complemented with comparative studies on karyotype morphology including species of the four subgenera. Thus, the hypothesis on reduction of the chromosome number proposed to explain the origin of Nothofagus may be robustly tested, and interpreted in a cytogeographic context to shed light on the studies that suggest South America as the most likely ancestral area for the genus, followed by New Zealand as the second most plausible source area (Swenson et al. 2000).

\section{ACKNOWLEDGEMENTS}

Thanks to CONAF Nursery (Corporación Nacional Forestal, Chile) for supply plants of Nothofagus species. To Ángel Contreras for image digitation.

\section{BIBLIOGRAPHY}

Armstrong, M. \& A. Wylie. 1965. A new basic chromosome number in the family Fagaceae. Nature 205: 1340-1341.

Carr, G. \& G. McPherson. 1986. Chromosome numbers of New Caledonian plants. Annals of the Missouri Botanical Garden 73(2): 486-489.

Dawson, M. 2000. Index of chromosome numbers of indigenous New Zealand spermatophytes. New Zealand Journal of Botany 38(1): 47-150.

Donoso, C., A. Premoli \& P. Donoso. 2004. Variación en Nothofagus siempre verdes sudamericanos. En: C.
Donoso, A. Premoli, L. Gallo \& R. Iliniza (eds.), Variación intraespecífica en las especies arbóreas de los bosques templados de Chile y Argentina, 145-166 pp., Editorial Universitaria, Santiago, Chile.

HaIr, J. 1966. Biosystematics of the New Zealand flora 19451964. New Zealand Journal of Botany 4: 559-595.

Harris, W. 1956. Pollen characters in Nothofagus. New Zealand Journal of Science and Biotechnology 37: 731-765.

HiLL, R. \& J. READ. 1991. A revised infrageneric classification of Nothofagus (Fagaceae). Botanical Journal of the Linnean Society 105: 37-72.

Hill, R. \& G. Jordan. 1993. The evolutionary history of Nothofagus. Australian Systematic Botany 6: 111-126.

Jordan, G. \& R. Hill. 1999. The phylogenetic affinities of Nothofagus (Nothofagaceae) leaf fossils based on combined molecular and morphological data. International Journal of Plant Sciences 160(6): 1177-1188.

Manos, P. 1997. Systematics of Nothofagus (Nothofagaceae) based on rDNA spacer sequences (ITS): Taxonomic congruence with morphology and plastid sequences. American Journal of Botany 84(8): 1137-1155.

Manos, P. \& A. Stanford. 2001. The historical biogeography of Fagaceae: Tracking the tertiary history of temperate and subtropical forest of the northern hemisphere. International Journal of Plants Sciences 162: 77-93.

Martin, P. \& J. Dowd. 1993. Using sequences rbcL to study phylogeny and biogeography of Nothofagus species. Australian Systematic Botany 6: 441-447.

NZPCN. 2013. New Zealand Plant Conservation Network. Nothofagus truncata. URL: http://www.nzpen.org.nz/ flora_details.aspx?ID=1039. Viewed: May 10, 2013.

Oginuma, K., R. Kiaptranis, K. Damas \& H. Tobe. 1998. A cytological study of some plants from Papua New Guinea. Shokubutsu Bunrui, Chiri 49(2): 105-114.

Ono, M. 1977. Chromosome number of some South American species of Nothofagus (Fagaceae). Botanical Magazine of Tokyo 90: 313-316.

Premoli, A., P. Mathiasen, M. Acosta \& V. Ramos. 2012. Phylogeographically concordant chloroplast DNA divergence in sympatric Nothofagus s.s. How deep can it be? New Phytologist 193: 261-275.

Setogushi, H., M. Ono, Y. Doi, H. Koyama \& M. Tsuda. 1997. Molecular phylogeny of Nothofagus (Nothofagaceae) based on the atpB - rbcL intergenic spacer of the chloroplast DNA. Journal of Plant Research 110: 469-484.

Swenson, U., R. Hill \& S. McLoughlin. 2000. Ancestral area analysis of Nothofagus (Nothofagaceae) and its congruence with the fossil record. Australian Systematic Botany 13: 469-478.

WARDLE, P. 1967. Biological flora of New Zealand. 2. Nothofagus menziesii Oerst. (Fagaceae). New Zealand Journal of Botany 5: 276-302.

Wiltshire, R. \& W. JACKSON. 2003. Index of chromosome numbers of Tasmanian spermatophytes. Papers and Proceedings of the Royal Society of Tasmania 137: 39-53. 